\title{
Forfald og fremskridt
}

\author{
HENRIK BORUP NIELSEN
}

Et af de mediebilleder, der i 1995 brændte sig fast på offentlighedens nethinde, forestiller to præsidenter: Den ene har åbenbart lige ladet en morsomhed undslippe sit underfundige pokerfjæs, for den anden vrider sig i et hysterisk grineflip, der kalder tårer frem i øjenkrogene og får det rødmossede ansigt til at skinne. Det minder mig om høringerne omkring hans ungdoms rygeoplevelse: „Mon han alligevel lærte at indhalere?" Hvad der starter som et jovialt klap på den humoristiske kollegas skulder, udvikler sig til noget, der ligner en fuld mands forhold til en lygtepæl, da mavekrampen sætter ind. Humoristen forpasser nu lejlighëden til at lade sig forarge over denne upassende opførsel og synes istedet at udstråle en underspillet selvtilfredshed med den reaktion, han har vækket hos sin vært. Så overgiver også han sig til latteren. Jeg spekulerer igen: „Han har jo også et problem med sit vodkaforbrug!"Scenen afspilles igen og igen verden over, helt frem til kavalkaderne over årets mest spektakulære begivenheder.

Uden at tillægge episoden større betydning gøres den af pressen til et utidigt brud på etiketten. Det er trods alt kun et af disse pressemøder efter officielle topmøder, der ikke forventes at præsentere væsentlige resultater, men blot skal formidle indtrykket af varme følelser mellem disse store mænd, i hvis hænder verdens skæbne er lagt. Spekulationerne i skæbnemagernes fysiske og åndelige habitus bliver aldrig alvorlige nok til at konkurrere med den menneskelige charme, der lægges for dagen - det er godt TV. Den slags der kan få produceren til at juble over en bonus-effekt, man aldrig kan forvente af officielle pressemøder. Et slagnummer på markedet for TV-nyheder. Den mere kritiske seer 
kan selvfølgelig spore den menneskelige charme tilbage til PRchefen: "Gi' ham et klap på skulderen, Bill. Vis verden, at I er venner!" Lad så gå, at han overspiller rollen lidt. Men hvad mon Boris' PR-chef har sagt?.Hvis han overhovedet har nogen! Hvad var det for resten, der var så morsomt?

Det handlede faktisk om pressen. Den havde med vanlig prognostisk sans forudsagt, at mødet mellem de to giganter ville blive en fiasko: De ville ikke nå til enighed om en fredsaftale for Bosnien, fordi Rusland tidligere havde nægtet at lade sine styrker indgå i NATO-kommandoen. $\mathrm{Nu}$ var en løsning imidlertid fundet, og det gav pressen anledning til at eftersøge den pludselige enighed i et princip, som en dansk statsmand engang har formuleret så præcist: „Man har et standpunkt, til man tager et nyt!" - et princip, som den fri presses veludviklede sans for konflikter hellere forbinder med svaghed og opportunisme end med argumentationens ædle kunst. Men i Boris fandt de en mand, der kunne give svar på tiltale: „To store præsidenter, Bill og Jeg, har store hjerner, og vi har truffet en beslutning, som ingen journalister kunne finde på! I har skrevet, at mit topmøde med Bill ville blive en komplet fiasko. Men det var en succes. Det er jer, der er en katastrofe!"

Bills reaktion får ekstra effekt af den kunstpause, han må udfylde med tænksomt opadskuende øjne, mens budskabet på hans modersmål toner frem i øresneglen med den professionelles neutrale stemmeføring. Han er oprigtigt overrasket. Han, der på sin vej til præsidentposten måtte løbe spidsrod gennem mediernes offentlige ransagning af hans personlige moral - lige fra afsløringerne af hans ungdoms rygeoplevelse og den upatriotiske undvigelse af militærtjeneste $i$ Vietnam til de stadige høringer i Whitewater-sagen - han oplever nu, at den mand, der personificerer den gamle arvefjendes bevægelse mod demokrati og markedsøkonomi, latterliggør disse medier for offentlig mening. Latteren udtrykker på en gang den frydefulde forestilling om selv at kunne gøre dette utænkelige og forlegenheden over at være vidne til kollegaens selvdestruktive angreb på 'Den 4. Magt'. Nok tog Boris formelt det afgørende skridt ud af Sovjetstaten, men han ejer ikke sin forgængers forståelse af den frie offentlig- 
heds magt. I den henseende er han en mand af det gamle regime: han har endnu ikke været på valg.

Billedet af de to store kom til at overskygge det officielle familiebillede, der skulle understrege topmødets historiske dimensioner: Alverdens statsledere samlet i New York for at fejre 50året for oprettelsen af de ForenedeNationer. 50-året for en verden der bekender sig til den evige fred, respekten for menneskerettighederne og solidariteten mellem folkeslagene - eller i hvert fald for en verden, der lader sig beskrive i misforholdet mellem idealerne og realiteterne. Det er den historie, vi får fortalt ved iscenesættelsen af begivenheden, der skulle være fejringen af den moderne tids enestående alliance mellem moral og politik historien om en fiasko. Realiteterne bliver endnu engang holdt op for idealernes domstol og krævet til ansvar for deres forsømmelser: „Hvorfor er der stadig krig, sult og fattigdom i verden?" Spørgsmål, der ikke længere trækker på nogen fremskridtsoptimisme, men snarere synes at have bevæget sig over en frustreret resignation til et rituelt gentaget mantra i mangel af bedre. Det er vel det selvfølgeligste af verden at spørge om - man kan slet ikke tillade sig at lade være. Alt andet ville være at overgive sig til barbariet. Vi må sikre en verden, hvor vi kan kræve vores ledere til ansvar såvel for den økonomiske verdensorden som for deres private transaktioner. Man skal kunne styre sig, for at kunne styre andre. Det er maximen, Bill til stadighed må leve op til. Boris er modsætningen som den selvtilstrækkelige statsmand hævet over offentlighedens kævl, men som statsmand kan denne ledertype indrømmes lige så store kvaliteter af de politiske kommentatorer. Kravet om moralsk integritet har sin naturlige modspiller i sansen for realiteterne, der aldrig lades i stikken af den oplyste offentlighed. I den sættes en verden på dagsordenen, der i godt 200 år har været spændt ud mellem idealer og realiteter, som den siden blev spændt ud mellem øst og vest. Verden ifølge Europa.

Her har ikke bare idealerne om fred, menneskerettigheder og solidaritet mellem folkeslagene deres udspring, men også den oplyste offentlighed båret af en fri presse. Disse fænomener kan faktisk slet ikke nævnes hver for sig, to sider af samme sag som 
de er. Hvis man kan påstå, at idealerne i FNs legemliggørelse forfalder, må man til gengæld indrømme den offentlighed, under hvis lys det sker, et glorværdigt fremskridt. Jeg vil fortælle historien om dette fremskridt.

Offentlighedens historie tog sin spæde begyndelse i oplysningstiden, der - som den store Kant gjorde opmærksom på endnu ikke var en oplyst tid, men blot den første tid der stod i oplysningens tegn. Længe før Kant skrev sine berømte kritikker, fik englænderne som de første pressefrihed i 1693 - fem år efter deres første nogenlunde demokratiske konstitution. Pressen var dog ikke mere fri, end at den først måtte tilkæmpe sig ret til at bringe referater fra den politiske offentlighed, hvilket ville sige parlamentet, hvor ikke alle var lige interesserede $i$ at stille deres afvejninger af argumenter og interesser til skue for publikum. Den almindelige bestikkelsespraksis tålte ikke pressens bevågenhed. Men hvor mange havde egentlig glæde af disse alenlange referater ud over det lille dannede publikum af adelige og borgerlige, der kunne finde sammen $i$ en fælles indignation under det reelle enevælde, som prægede hele Europa efter 30-årskrigens kaos. Dette publikum dannede forestillingen om en dannelse for dannelsens egen skyld, der udsprang af de besiddendes kulturelle såvel som økonomiske overskud, og som derfor naturligt udviklede sig fra en litterær offentligheds adspredelser til en politisk offentligheds magtkrav. Først længe efter borgerskabets revolution i Frankrig gik det op for dem, at den nødvendige sammenhæng mellem at være en politisk aktiv og en økonomisk aktiv borger kunne anfægtes. Demokratiske rettigheder kunne i længden ikke forbeholdes de besiddende - hvis man da ikke kunne gøre alle til besiddere. I den stadig udvidede valgrets irreversible fremskridt havde den frie presse en stor del af æren. Skulle nogle i dag foreslå, at denne ret fratages de arbejdsløse, vil pressen straks vide at placere dem på et reaktionært overdrev, grænsende til det facistoide, skønt det er i identifikationen af den besiddende borger med mennesket, at oplysningen har sine rødder. Den kloge Rousseau skrev ganske vist, at ejendomsretten var roden til civilisationens onde, hvorfor det rent menneskelige altid ville stå i modsætning til rollen som borger i en stat, der 
gjorde den fri ejendomsret gældende. Men den liberale oplysning vidste, at kun som besiddende samfundsborger kunne man fungere som autonomt individ i forhold til staten, og kun som autonom var man fri til at lade det rent menneskelige være bestemmende i den borgerlige offentligheds frie meningsdannelse. Længe leve de autonome! Da først oplysningens kim var lagt, måtte den jo brede sig til masserne.

Pressen fortsatte som bæreren af denne oplysning i en sindrig alliance med staten. I takt med at staten organiserede alfabetiseringen af folket, konsoliderede pressen sig som 'Den 4. Magt', der skærpede sin kontrol med staten ved at oplyse det udvidede publikum om dens dispositioner og om nødvendigt anfægte legitimiteten af dem. Det 19. århundrede blev avisens århundrede. Oplagene voksede så kollosalt, at aviserne udviklede sig fra at være en udgiftskrævende bibeskæftigelse for politisk interesserede rigmænd og idealistiske brusehoveder til at blive et investeringsobjekt på linie med storindustrien. Det var altså først i slutningen af det 19. århundrede, at pressen løsrev sig fra en lille elites diktat for at blive massernes medium og dermed en sand afspejling af den offentlige mening, der udfoldede sig i dem. Væk var den sværmeriske Rousseaus nedvurdering af den offentlige mening i den forældede skelnen mellem en plebsitær volonté de tous over for en mystisk volonté générale, som det kun var den forundt at afkode, der besad tilstrækkelig med bon sens. Glemt var den spidsfindige Kant, der i sit lille skrift Til den evige Fred anfægtede de nye demokratiers egen forståelse af deres statsdannelser som resultatet af en demokratisk proces, ved at hævde en oprindelig kontrakt, der konstituerede staten ved at indordne alles viljer under en almenvilje, der så først dannede mulighedsbetingelsen for en republikansk forfatning, som iøvrigt aldrig kunne være demokratisk, da dette ville være et tilbagefald til alle viljers kaotiske kamp, som kun fører til despoti. Men hvem fatter alligevel noget af det? De få, der ville bilde det nye store læsepublikum ind, at der skulle være uoverensstemmelse mellem, hvad det interesserede sig for og hvad der var i dets interesse, fik det sværere. Selvfølgelig med en væsentlig undtagelse i kommunisterne der fortalte arbejderne, at de selv 
måtte gøre sig til besiddere af det, de ville have, hvis de ville opnå autonomi. Den politiske offentlighed lod sig nu ikke længere begrænse til parlamenterne, men omfattede hele den meningsudvekslende offentlighed som pressen selv var en del af. Denne pluralisme led som bekendt en krank skæbne, hvor kommunisterne satte sig i besiddelse af alle trykpresser, men i Europa betegnede ordet 'partipresse' en mangfoldighed af partier med hver sin presse.

Pressens mellemværende med staten var ikke dermed slut, for dette kolde uhyre vil til stadighed hævde sig i stand til at kende borgernes interesser bedre end borgerne selv, hvilket sammen med misrygt af loven er den væsentligste årsag til, at den til stadighed nedkalder 'Den 4. Magts' årvågne blik over sin gerning. Nok var der igen en sælsom alliance på spil i første halvdel af dette århundrede, da radiomediet blev lanceret inden for statens økonomiske og bureaukratiske rammer som public service for senere at blive tilgængeligt for private initiativer. Men man kunne jo heller ikke have forlangt, at pressen skulle financiere alfabetiseringen. Denne omsorg for borgernes interesser måtte derfor blive genstand for en sund mistænkeliggørelse, der i sidste ende rettede sig mod de socialdemokratiske statsbureaukratiers formynderiske tilbøjelighed for forvaltning af borgernes liv fra vugge til grav. Den frie presse har igen sin store del af æren for, at denne public service i løbet af det sidste halve århundrede er blevet omdefineret fra en elitær udlægning af borgernes interesser til en stadig mere fintfølende afkodning af de interesser borgerne faktisk lader komme til udtryk - når blot man ser efter. Samtidig er begrebet 'presse' med dets associationer til mekanisk reproduktion efterhånden blevet fortrængt af det mere rummelige begreb 'medier'. Paradigmatisk for dette fremskridt er de danske TV-kanaler, der først ved overgangen til den aktuelle konkurrencesituation forlod forestillingen om en public interest for helt at koncentrere sig om service-aspektet. Denne service mindede tilgang stikker langt dybere end de trivielle konstateringer af, at underholdningsafdelingerne sender det samme lort på de samme tidspunkter. Den manifesterer sig først og fremmest i et fænomen, der karakteriserer og udmærker det moderne Europa 
mere end nogen anden civilisation i historien, nemlig selvrefleksivitet. Denne selvrefleksivitet kommer til udtryk i den seismografiske nøjagtighed, med hvilken ikke bare statsradiofonierne, men hele pressen formidler mellem staten og masserne, politikerne og folket, forbrugerne og producenterne. Nyhedsformidlingen er ikke længere blot en indsamling og viderebringning af information, men er i sin mest avancerede form blevet selvtematiserende. Den kritiske journalist nøjes ikke længere med at kritisere, men kan nu lægge bevidstheden om effekten af sin egen kritik oven i den blotte oplysning. Man spørger ikke blot ministeren, hvad han vil gøre ved sagen, men derimod hvilke konsekvenser en 'dårlig presse' mon vil få ved næste valg, hvis det ikke lykkes ham at genoprette borgernes tillid. Dårlig presse er således blevet den største trussel over for uredelighed og hemmelighedskræmmeri.

Den ny presse har en nær allieret i en særlig variant af sandsynlighedsregningen: meningsmålingerne. De udgør den seismograf, der afkoder borgernes interesser og bringer dem frem i offentligheden i deres reneste form. Med matematisk præcision gennemtrænger meningsmålingerne masserne og omformer det tilsyneladende amorfe til et klart og distinkt billede. Det er billedet af den offentlige menings bevægelser, som enhver politiker med respekt for sin karriere må tage til efterretning, og det er billedet af forbrugernes stadig mere nuancerede krav om økologisk forsvarlighed og politisk korrekthed. I tillæg til bevidstheden om effekten af dens egen kritik på massernes meningsdannelse lægger pressen disse afkodninger af meningsdannelsen frem for masserne selv og åbner derved massernes egne muligheder for selvrefleksion. Her er jeg! Borger i det moderne demokrati. Jeg afgiver min stemme ved hvert valg, men jeg gør det også, når jeg handler i supermarkedet. Jeg kan nemlig stemme den fede og kemikalieholdige spegepølse ud til fordel for den økologiske med statsgaranti. Jeg er ikke begrænset til at stemme på Poul eller Uffe i Danmark, men kan i vinafdelingen også gøre min indflydelse gældende over for Jacques i Frankrig, når han sprænger atombomber på Muroroa. Mon der ikke også er en afdeling, hvor jeg kan støtte Boris' demokratiseringsbestræbelser og flere, hvor jeg 
kan sætte en grænse for Bills kultureksport. Mens partierne er ved at indføre det politiske supermarked ved at udforme deres valgprogrammer som varekataloger, er supermarkederne selv allerede blevet politiske. Selv med min beskedne indtægt (i form af en overførselsindkomst fra staten) er jeg i besiddelse af en politisk indflydelse, som jeg slet ikke kan unddrage mig. En indflydelse jeg gerne indrømmer at føle som et tyngende ansvar - særligt når jeg køber æg. Jeg følger nemlig med i medierne, og medierne følger med i mig, når de politiske analyser går lige til benet og konfronterer de ansvarlige politikere og erhvervsledere med konsekvenserne af vælgernes og forbrugernes dom. Som en flok piratfisk når en blodsdråbe rammer vandoverfladen - så hurtigt kan vi vende os på et givent signal, og dagen efter kan vi høre om det $i$ alle medier. Det er faktisk i medierne, det hele foregår, for de formidler både færten af blod, massernes reaktion og refleksionen over mediernes egen betydning i denne proces. Som autonom borger $i$ et moderne demokrati kan jeg lade det rent menneskelige komme til udtryk som vælger og forbruger, men uden medierne ville jeg ikke have en jordisk chance for at overskue den socialitet, som masserne udgør, endsige kunne forsikre mig om deres eksistens. Derfor hedder det 'massemedier'.

$\mathrm{Nu}$ er den oplyste offentlighed som antydet ikke nogen helt entydig størrelse, og derfor gøres der til stadighed modstridende synpunkter gældende om dens idealer, såvel som om dens historie og dens aktuelle status. Nogen vil måske hævde, at min beretning om pressen og.de moderne medier langt fra at beskrive en glorværdig udvikling faktisk er historien om offentlighedens forfald. De tager fejl. Vil man se offentlighedens udvikling fremstillet som en forfaldshistorie, må man gå andre veje. Det er endda gjort af én, hvis uomtvistelige kapacitet kun kan stille min beskedne version i et tvivlsomt skær. Jürgen Habermas' stærke kritik af den borgerlige offentlighed får tilmed ekstra vægt af, at han samtidig er den største nulevende forsvarer for det europæiske oplysningsprojekt. Over for styrken i hans argumentation blegner ethvert forsøg på afvisning - endsige ironisk distance. Den samvittighedsfuldhed med hvilken han forfølger sit projekt, gør 
ham til et barometer på den europæiske drøm om frihed, oplysning og retfærdighed.

I sin bog Strukturwandel der Öffentlichkeit fra 1962 beskriver Habermas den borgerlige offentligheds forfald med udgangspunkt i den borgerlige offentlighed selv som idealtypisk kategori. Med sine rødder i den Marx-inspirerede Frankfurter-skole er han ofte blevet udsat for venstreorienteret kritik af sin borgerlighed, men heroverfor fastholder han, at det ikke er de borgerlige idealer, der er noget galt med. De skal blot vendes mod borgerskaber selv for at vise, hvordan de forfalder. Idealet om borgerlig offentlighed bygger i sit udgangspunkt på det offentlige ræsonnement som kernen i en fri demokratisk menings- og viljesdannelse. Habermas er mere end nogen bevidst om, at dette ideal aldrig har været realiseret i en herredømmefri kommunikation, men de autonome privatfolks deltagelse i det offentlige ræsonnement og deres samling som publikum dannede netop den offentlighed, der kunne fungere som en kritiks '4. Magt' over for det politiske og sociale herredømme, som satte sig ud over delingen $\mathrm{i}$ øvrighedens udøvende, lovgivende og dømmende magt. Strukturforandringen, der efter hans opfattelse umuliggør denne kritiske funktion, sætter ind i det 19. århundrede, idet pressen selvstændiggør sig over for publikum og udvikler sig til en kommerciel avisindustri. Fra at være formidler af nyheder til borgerne og af borgernes egne ræsonnementer til publikum bliver pressen den materielle bærer af en offentlig mening. Denne nye form for offentlig mening er imidlertid ikke resultatet af det offentlige ræsonnement, men derimod et anonymt og abstrakt fænomen, der skabes af de nye massemedier. Mens den offentlige mening mister sit ansvarlige subjekt og dermed sin menneskelighed, forsvinder ræsonnementet ind i partiernes og organisationernes lukkede og begrænsede 'offentligheder' og reducerer den politiske offentlighed til en kampplads for de modstridende interesser.

At den politiske offentlighed forfalder er imidlertid ikke ensbetydende med, at det oplysningsprojekt, den har sine rødder i, har spillet fallit. Bag dette forfald i formerne skriver der sig et fremskridt i rationalitet, som er særegent for den moderne euro- 
pæiske oplysningstradition. I kæmpeværket Theorie des kommunikativen Handelns fra 1981 fremstilles dette fremskridt eksemplarisk i sprogfilosofiens og sociologiens teorihistorie, hvor princippet om det bedre arguments forrang har ført teorierne mod en stadig højere grad af rationalitet. Men ikke kun på det teoretiske niveau kan fremskridtet påvises. Hvor Kant sporede de højeste idealer tilbage til de transcendentale principper for den menneskelige erkendelse, dér finder Habermas dem i hverdagssprogets strukturer, der bærer implicitte referencer til gyldighedskrav om sandhed, retfærdighed og oprigtighed. Gyldighedskravene er ganske vist historiske dannelser, men de har i udviklingen af den moderne tradition sedimenteret sig som det fælles grundlag, der udgør kernen i vores socialitet. Hvor religionen engang lagde sit autoritære åg over vort fællesskab, der har oplysningen siden frisat rationaliteten, hvis normative grundlag kan uddrages af sprogets implicitte strukturer. Sproget - dette mediernes medium - som bæreren af de ædleste frugter fra den europæiske oplysningstradition. Skade blot, at det ikke forvaltes bedre.

Som institution i verdenssamfundet er De forenede Nationer den synlige bærer af samme oplysningstradition - en europæisk tradition, der har forsøgt at inddrage hele verden. I FNs officielle retorik kan man stadig møde forestillingen om friheden, menneskerettighederne og solidariteten som absolutte universelle principper, hævet over kultur og historie, mens organisationens praktiske arbejde viser sig som pragmatiske forsøg på at afgrænse partikulære interesser, der ikke vil vide af disse principper. Konfrontationen mellem idealer og realiteter henviser således idealerne selv til deres partikulære kulturelle baggrund. Habermas' heroiske forsvar for oplysningsprojektet afspejler denne bevægelse i videreførelsen af universalismen i en universalpragmatik, der ikke længere gør krav på at være absolut, men refererer til en historisk og kulturel 'livsverden', i hvilken det universelle er blevet formaliseret til en modus, der udgør det uomgængelige vilkår for intersubjektiv kommunikation. Det moderne oplysningsprojekt er i denne horisont et ufuldendt projekt og Habermas' eget værk er barometeret, der følger projektets bevægelser. Når vi ikke længere naivt kan hævde den europæi- 
ske kulturs overlegenhed, så skulle vi dog i universalpragmatikken have et produkt af den europæiske kultur, der med rette kan gøres gældende globalt og måske forklarer denne kulturs dominans. Men når vi overhovedet er kommet så vidt, er det fordi barometerstanden viser, at det europæiske forsøg på globalisering af de universelle idealer har genopdaget dem som det, de er - europæiske.

Europa har lært at begrænse sig. Udadtil som en kultur blandt andre kulturer, som man enten afgrænser sig i forhold til, fordi de aggresivt afviser vores idealer, eller udgrænser økonomisk, fordi de ikke kan leve op til dem. Indadtil viser begrænsningen sig i forskellige former for selvrefleksivitet, der bliver til under indtryk af mødet med oplysningens grænser - de geografiske såvel som de logiske, der udspringer af oplysningen selv. Habermas gør en dyd ud af denne begrænsning i sin redelige og samvittighedsfulde indoptagelse af alle oplysningens aporier i fortsættelsen af oplysningsprojektet. Massemedierne er den bevidstløse parodi på begrænsningen, når de tematiserer deres egne effekter, der præsenteres af journalister, som manisk fastholder forestillingen om, at de i oplysningens navn friholder et sted, hvorfra objektivitetens klare lys skinner. Hvor Habermas indoptager begrænsningen i sin refleksion, der er massemedierne en uafvidende eksemplificering af den i begrænsningen af deres egen horisont til de masser, de selv sætter i scene. Sidstnævnte er således en taknemmelig genstand for førstnævntes tematisering af forfaldet, men forsvaret for oplysningens fortsatte fremskridt har selv brug for et forfald at afgrænse sig i forhold til. Det gælder Habermas' teori såvel som den oplyste presses indignerede dom over statsoverhovedernes manglende evne til at leve op til idealerne og bringe lidelsen ud af verden. Fremskridtet kender intet andet alternativ end forfaldet. Forfaldet er ikke kun konsekvensen af idealernes sammenstød med realiteterne, men også den negation der allerede er indeholdt $\mathrm{i}$ idealerne selv. Udadtil kan dette dilemma komme til udtryk som pragmatiske forsøg på at holde europæiske værdier i hævd, eller som resignerede erkendelser af den vold, Europa har øvet på verden. Pragmatikken findes i mange afskygninger såvel som syndsbe- 
vidstheden, der altid glemmer, at når vi i Europa har opfundet begrebet etnocentrisme, er det ikke fordi vi er mere etnocentristiske end andre, men fordi vi er de eneste, der reflekterer over, at vi er det. Under indtryk af dette kan man indadtil tematisere forfald og fremskridt i en ny selvrefleksion, der forsøger at gøre sig gældende som offentligt ræsonnement. 